\title{
The Effects of Sago (Metroxylon sagu) Bark and Frond Waste as Substrates on the Growth and Yield of Grey Oyster Mushrooms (Pleurotus sajor-caju)
}

\author{
Haslinza Senghie, Mohamad Hasnul Bolhassan* and Dayang Salwani Awg-Adeni \\ Faculty of Resource Science and Technology, Universiti Malaysia Sarawak, Jalan Datuk Mohammad Musa, \\ 94300, Kota Samarahan, Sarawak, Malaysia
}

\begin{abstract}
This study was carried out to examine the effects of sago bark (SB) and sago frond (SF) waste on the growth and yield of grey oyster mushrooms (Pleurotus sajor-caju). Nine substrate formulas were studied, including sawdust (SD) alone as a control and the combination of 25:75, 50:50, and 75:25 ratios between SD and SB or SF. The results showed a significant difference in the total colonisation period, total fruiting body yield, and biological efficiency (BE). However, an insignificant difference was determined in the characteristics of the fruiting body for different substrate formulas. The substrates with the ratio of 50SD:50SF and $100 \mathrm{SD}$ are the most suitable substrate formulas for the cultivation of $P$. sajor-caju. One hundred (100) SD achieved the fastest total colonisation period (24.44 days) but there was no significant difference with 75SD:25SF (24.78 days) and also obtained the fastest first harvest (50.33 days). However, 100SD produced a significantly lower total fruiting body yield (77.99 g/bunch) compared to 50SD:50SF, which produced the highest total yield $(88.09 \mathrm{~g} /$ bunch) and highest BE (17.62\%) with a

ARTICLE INFO

Article history:

Received: 6 October 2020

Accepted: 4 February 2021

Published: 28 May 2021

short total colonisation period (26.45 days). The substrates produced high values in cap diameter, stipe length, and effective fruiting bodies.
\end{abstract}

DOI: https://doi.org/10.47836/pjtas.44.2.04

E-mail addresses:

haslinzasenghie@gmail.com (Haslinza Senghie)

bmhasnul@unimas.my (Mohamad Hasnul Bolhassan)

adsalwa@unimas.my (Dayang Salwani Awg-Adeni)

*Corresponding author
Keywords: Mushroom cultivation, sago bark, sago frond, waste, yield 


\section{INTRODUCTION}

Oyster mushroom (Pleurotus sp.) was cultivated worldwide throughout the previous few decades (Royse, 2002). Due to white mycelium production, Pleurotus $\mathrm{sp}$. is associated with the white-rot fungi group and under the class basidiomycetes (Tsujiyama \& Ueno, 2013). The common name 'oyster' comes from the white shell-like shape of the fruiting body of the mushroom. Pleurotus sp. is among the most popular mushroom worldwide in terms of edible basidiomycetes. This species stands in third place in the yield of eatable mushrooms following Agaricus and Lentinula genus species (Cardoso et al., 2013). Pleurotus sajor-caju is the most famous cultured species among these mushrooms and acknowledged for its deliciousness (Zhang et al., 2002).

Mushroom cultivation could be a procedure that helps in waste disposal and environmental waste management. Oyster mushroom cultivation has a major part in managing organic waste wherever dumping becomes difficult (Das \& Mukherjee, 2007). An example of organic waste found in Malaysia, particularly in Sarawak, is sago palm tree waste.

Palms come under one of the oldest families of plants on earth (Hisahima, 1995). One of them is sago palm or scientifically known as Metroxylon sagu, which is utilised as an essential crop in Southeast Asia due to the high quantity of starch within the trunk. Sago palm is one of the most affordable and convenient food starch sources with the highest starch production per land area compared to different starch products (Rajyalakshmi, 2004). However, problems arise with the expansion of sago starch production in terms of the residues left from sago palm trees, such as trunk bark (cortex) and frond that pollute the environment. To collect edible starch, the whole tree needs to be cut down to collect the inner trunk, and with the increased production of sago palm, a large amount of fibrous waste and trunk bark is left in starch mills, which pollute the environment (Kuroda et al., 2001). According to Ngaini et al. (2014), 15.6 tons of sago woody bark and 7.10 tons of fibrous pith waste from 600 logs of sago palm are generated in a day. The abundance of sago starch waste has created environmental problems as the waste accumulates in fields or is burned (Awg-Adeni et al., 2009).

Therefore, residue utilisation is needed to overcome this issue. One way to utilise sago palm waste is to convert the waste into a substrate for mushroom cultivation. The possibilities for sago palm waste fibre as a mushroom cultivation substrate have not been totally explored. The aim is to determine the alternative substrate for the cultivation of $P$. sajor-caju.

This study was performed to study the performance of various substrate formulas consisting of sago bark (SB), sago frond (SF), and sawdust (SD) waste on the growth and yield of $P$. sajor-caju.

\section{MATERIALS AND METHODS \\ Pure Culture and Spawn Preparation}

Grey oyster mushroom was collected from a local market and identified as P. sajor- 
caju by using a molecular identification technique. Potato dextrose agar (PDA) medium was used to grow P. sajor-caju at $28^{\circ} \mathrm{C}$ for pure culture and maintained on the PDA medium at $4{ }^{\circ} \mathrm{C}$ for at most three months. Paddy grains were used for spawn preparation. The spawns were prepared in $850 \mathrm{ml}$ polypropylene plastic bags and PVC tubing was used to close the bags' mouth. The bags were autoclaved at $121^{\circ} \mathrm{C}$ for 15 min and left to cool at room temperature. Sterilised paddy grains were inoculated with viable mycelia of $P$. sajor-caju from the PDA medium and incubated at $28^{\circ} \mathrm{C}$ until the mycelia fully colonised the bags.

\section{Substrate Preparation and Spawn Inoculation}

The substrates used in this study were mill $\mathrm{SD}, \mathrm{SB}$, and SF. The SD was obtained from a local wood factory. All the sago substrates were obtained from a local sago grower in Lundu, Sarawak, Malaysia. Approximately $5 \mathrm{~kg}$ of SB and SF were sundried for a week until the waste dried and then ground by a grinding machine into $0.5-1.5 \mathrm{~cm}$ length pellets. To determine appropriate substrates and ratios towards grey oyster mushroom cultivation, nine substrate formulas along with $\mathrm{SD}, \mathrm{SB}$, and SF alone and the mixtures of 25:75, 50:50, 75:25 ratios consisting of SD with SB and SF (on a dry weight basis) were studied. One hundred per cent (100\%) SD substrate was utilised as the control treatment. The data were presented as 100SD, 75SD:25SB, $50 \mathrm{SD}: 50 \mathrm{SB}, 25 \mathrm{SD}: 75 \mathrm{SB}, 100 \mathrm{SB}$, 75SD:25SF, 50SD:50SF, 25SD:75SF, and
100SF. After mixing the materials at these ratios, they were prepared using a 100:1:1 ratio for the sample $(500 \mathrm{~g})$ :rice bran:chalk $\left(\mathrm{CaCO}_{3}\right)$. Around $65 \%$ of the water content was adjusted for the ultimate mixture. Each substrate formula was packed into polyethylene plastic bags and sterilised in an autoclave for $15 \mathrm{~min}$ at $121^{\circ} \mathrm{C}$ and left to cool at room temperature. Next, each bag was inoculated with $10 \mathrm{~g}$ spawn per bag and three culture bags were prepared for each substrate formula.

\section{Substrate Incubation and Fruiting Body Harvesting}

The inoculated substrate bags were maintained inside the incubation room at $28{ }^{\circ} \mathrm{C}$ and $60 \%-70 \%$ relative humidity. The bags were placed on a mushroom shelf outside the Faculty of Resource Science and Technology, Universiti Malaysia Sarawak (UNIMAS) once the substrate bags were entirely covered with mycelium. Three mushroom flushes were harvested from every bag for each substrate formula and the total days taken from inoculation until the first harvest was inspected and documented. Any contamination was monitored throughout cultivation. The weight $(\mathrm{g} / \mathrm{bunch})$ of individual bunch of mushrooms per bag and proportion of flushes (stipe length and cap diameter) of the harvested fruiting bodies were measured and recorded. The amount of effective fruiting bodies per bag at the first, second, and third flushes and the total means were recorded per bag ( $\mathrm{g} / \mathrm{bag})$. The collected data were applied to calculate the total yield 
and biological efficiency (BE) after the harvesting period end. BE was calculated using the following equation and the results were recorded:

$$
\mathrm{BE}(\%)=\frac{\text { Grams of fresh sporophore produced }}{\text { Grams of dry substrate used }} \times 100 \%
$$

\section{Experimental Design and Data Analysis}

The research was performed in the Mycology Laboratory, Faculty of Resource Science and Technology, UNIMAS in Malaysia from January 2018 until September 2019. The experiment was arranged in a randomised complete block design with three replications and three cultured bags per treatment in each replication. The collected data were inspected using IBM SPSS Statistics 20. The differences between the substrates were compared using one-way analysis of variance. The test of significance with $p$-value $<0.05$, which is considered significant, was done using Tukey HSD multiple range test. All data were expressed as mean \pm standard error.

\section{RESULTS AND DISCUSSION}

Effects of Various Substrate

Formulas on Grey Oyster Mushroom Morphological Parameters

Nine substrate formulas were tested to determine the growth and yield of $P$. sajor-caju. No visible contamination was observed for all substrate formulations during spawning and cultivation throughout this study. The results in Table 1 display significant differences in the morphological parameters of $P$. sajor-caju cultivated using nine non-identical substrate formulas. The colonisation of $P$. sajor-caju mycelia on the substrate bags was completed between 24.44 and 28.78 days after incubation. The substrate containing $100 \%$ SD was completely colonised by mycelia in a shorter time (24.44 days) while 100\% SB took the longest time (28.78 days) than other substrate formulas. Mycelium growth in this research was much slower than the previous study (Emiru et al., 2016), showing that oyster mushroom mycelium took 2-3 weeks to colonise the SD substrate bag after complete inoculation. One of the reasons may be due to high carbon/nitrogen $(\mathrm{C} / \mathrm{N})$ ratio of SB and SF waste substrate. Naraian et al. (2009) stated that mycelium growth development and pinhead formation rely on the $\mathrm{C} / \mathrm{N}$ ratio in substrates. A low $\mathrm{C} / \mathrm{N}$ ratio gives higher results of fruiting bodies and supports better mushroom yield (Royse, 2002). Fresh sago waste contained the $C / N$ ratio of 790.1 (Auldry et al., 2009) while SD contained the $\mathrm{C} / \mathrm{N}$ ratio of 325.0 (Osunde et al., 2019).

The fastest first harvest collected for P. sajor-caju (50.33 days) was recorded from the substrate formula of 100SD and significantly quicker than other substrate formulas, whereas the longest period taken for the first harvest collected (71.86 days) was obtained from the substrate formula of $100 \mathrm{SB}$. The days for the colonisation period of mycelia and the first harvest of 
P. sajor-caju were shorter for the substrate formula of 100SD, whereas 100SB took the longest time compared to other substrate formulas. These results supported the finding of a previous study, in which a substrate with a higher ratio of SD has the fastest duration for mycelia to completely colonise the bags (Shah et al., 2004). The current experimentation outcomes agreed with Bugarski et al. (1994), who stated that the first fruiting body occurred on different days, depending on the substrates.

Table 1

Effect of various substrate formulas on morphological parameter and characteristics of fruiting body of Pleurotus sajor-caju

\begin{tabular}{|c|c|c|c|c|c|c|}
\hline $\begin{array}{l}\text { Substrate } \\
\text { formula }\end{array}$ & $\begin{array}{c}\text { Total } \\
\text { colonization } \\
\text { period (day) }\end{array}$ & $\begin{array}{c}\text { First } \\
\text { harvest } \\
\text { (day) }\end{array}$ & $\begin{array}{c}\text { Cap } \\
\text { diameter } \\
(\mathrm{mm})\end{array}$ & $\begin{array}{c}\text { Stipe } \\
\text { length } \\
(\mathrm{mm})\end{array}$ & $\begin{array}{l}\text { No. of } \\
\text { effective } \\
\text { fruiting } \\
\text { bodies/ } \\
\text { bunch }\end{array}$ & $\begin{array}{c}\text { Fruiting } \\
\text { bodies } \\
\text { weight } \\
\text { (g/bunch) }\end{array}$ \\
\hline $100 \mathrm{SD}$ & $\begin{array}{c}24.44 \pm \\
0.84^{\mathrm{a}}\end{array}$ & $\begin{array}{c}50.33 \pm \\
3.35^{\mathrm{a}}\end{array}$ & $\begin{array}{c}7.30 \pm \\
1.10^{\mathrm{a}}\end{array}$ & $\begin{array}{c}6.57 \pm \\
0.71^{\mathrm{a}}\end{array}$ & $\begin{array}{c}2.13 \pm \\
0.42^{\mathrm{a}}\end{array}$ & $\begin{array}{c}26.00 \pm \\
3.75^{\mathrm{ab}}\end{array}$ \\
\hline $75 \mathrm{SD} 25 \mathrm{SB}$ & $\begin{array}{c}25.00 \pm \\
0.89^{\mathrm{ab}}\end{array}$ & $\begin{array}{c}59.46 \pm \\
1.08^{\mathrm{ac}}\end{array}$ & $\begin{array}{c}7.87 \pm \\
0.57^{\mathrm{a}}\end{array}$ & $\begin{array}{c}6.40 \pm \\
0.44^{\mathrm{a}}\end{array}$ & $\begin{array}{c}1.70 \pm \\
0.20^{\mathrm{a}}\end{array}$ & $\begin{array}{c}19.17 \pm \\
2.74^{\mathrm{b}}\end{array}$ \\
\hline 50SD 50SB & $\begin{array}{c}27.22 \pm \\
1.71^{\mathrm{ac}}\end{array}$ & $\begin{array}{c}53.90 \pm \\
4.01^{\mathrm{ac}}\end{array}$ & $\begin{array}{l}7.53 \pm \\
1.11^{\mathrm{ac}}\end{array}$ & $\begin{array}{c}6.87 \pm \\
1.27^{\mathrm{a}}\end{array}$ & $\begin{array}{c}1.70 \pm \\
0.56^{\mathrm{a}}\end{array}$ & $\begin{array}{c}19.99 \pm \\
3.39^{\mathrm{b}}\end{array}$ \\
\hline $25 \mathrm{SD} 75 \mathrm{SB}$ & $\begin{array}{c}27.33 \pm \\
1.34^{\mathrm{ac}}\end{array}$ & $\begin{array}{c}63.10 \pm \\
0.35^{\mathrm{bc}}\end{array}$ & $\begin{array}{c}7.70 \pm \\
0.69^{\mathrm{a}}\end{array}$ & $\begin{array}{c}6.77 \pm \\
0.50^{\mathrm{a}}\end{array}$ & $\begin{array}{c}1.67 \pm \\
0.12^{\mathrm{a}}\end{array}$ & $\begin{array}{c}19.70 \pm \\
0.59^{\mathrm{b}}\end{array}$ \\
\hline $100 \mathrm{SB}$ & $\begin{array}{c}28.78 \pm \\
2.14^{\mathrm{c}}\end{array}$ & $\begin{array}{c}71.86 \pm \\
5.17^{\mathrm{b}}\end{array}$ & $\begin{array}{c}8.37 \pm \\
0.55^{\mathrm{b}}\end{array}$ & $\begin{array}{c}7.47 \pm \\
0.81^{\mathrm{a}}\end{array}$ & $\begin{array}{c}1.83 \pm \\
0.50^{\mathrm{a}}\end{array}$ & $\begin{array}{c}21.66 \pm \\
1.75^{\mathrm{ab}}\end{array}$ \\
\hline $75 \mathrm{SD} 25 \mathrm{SF}$ & $\begin{array}{c}24.78 \pm \\
0.19^{\mathrm{a}}\end{array}$ & $\begin{array}{c}67.43 \pm \\
1.63^{\text {bd }}\end{array}$ & $\begin{array}{c}6.70 \pm \\
0.46^{\mathrm{a}}\end{array}$ & $\begin{array}{c}6.13 \pm \\
0.76^{\mathrm{a}}\end{array}$ & $\begin{array}{c}2.16 \pm \\
0.57^{\mathrm{a}}\end{array}$ & $\begin{array}{c}23.18 \pm \\
3.37^{\mathrm{ab}}\end{array}$ \\
\hline 50SD 50SF & $\begin{array}{c}26.45 \pm \\
1.35^{\mathrm{ac}}\end{array}$ & $\begin{array}{c}59.00 \pm \\
7.37^{\mathrm{ad}}\end{array}$ & $\begin{array}{c}8.07 \pm \\
1.00^{\mathrm{a}}\end{array}$ & $\begin{array}{c}6.60 \pm \\
0.40^{\mathrm{a}}\end{array}$ & $\begin{array}{c}2.13 \pm \\
0.70^{\mathrm{a}}\end{array}$ & $\begin{array}{c}29.36 \pm \\
5.19^{\mathrm{a}}\end{array}$ \\
\hline $25 \mathrm{SD} 75 \mathrm{SF}$ & $\begin{array}{c}26.67 \pm \\
0.67^{\mathrm{ac}}\end{array}$ & $\begin{array}{c}69.00 \pm \\
1.30^{\mathrm{bc}}\end{array}$ & $\begin{array}{c}6.87 \pm \\
0.65^{\mathrm{a}}\end{array}$ & $\begin{array}{c}6.07 \pm \\
0.32^{\mathrm{a}}\end{array}$ & $\begin{array}{c}1.93 \pm \\
0.64^{\mathrm{a}}\end{array}$ & $\begin{array}{c}20.39 \pm \\
3.23^{\mathrm{b}}\end{array}$ \\
\hline $100 \mathrm{SF}$ & $\begin{array}{c}27.56 \pm \\
0.77^{\text {ac }}\end{array}$ & $\begin{array}{c}67.33 \pm \\
2.03^{\text {bc }}\end{array}$ & $\begin{array}{c}7.300 \pm \\
2.23^{\mathrm{a}}\end{array}$ & $\begin{array}{c}6.67 \pm \\
1.51^{\mathrm{a}}\end{array}$ & $\begin{array}{c}1.77 \pm \\
0.40 \mathrm{a}\end{array}$ & $\begin{array}{c}22.55 \pm \\
1.36^{\mathrm{ab}}\end{array}$ \\
\hline
\end{tabular}

Note. Significant at 0.05 level in ANOVA; mean values with the same lower-case letters are not significantly different according to Tukey HSD's mean separation test. SD, sawdust; SB, Sago bark; SF, Sago frond

Effects of Various Substrate Formulas on Grey Oyster Mushroom Fruiting Body Characteristics

There were no significant differences in the cap diameter and stipe length of $P$. sajor-caju grown on nine different substrate formulas (Table 1). The highest cap diameter $(8.37 \mathrm{~cm})$ was recorded for 
the substrate formula 100SB and the lowest diameter $(6.70 \mathrm{~cm})$ was documented for the substrate $75 \mathrm{SD}: 25 \mathrm{SF}$. The length of the stipe ranged from $6.07 \mathrm{~cm}$ to $7.47 \mathrm{~cm}$ (Table 1). One hundred (100) SB recorded a higher mean cap diameter and the longest stipe length than other substrate formulas, although no significant differences were recorded between each substrate formula. By referring to the Federal Agricultural Marketing Authority (FAMA) (2012) on the grade requirement for fresh grey oyster mushroom (MS 2515:2012), all nine substrate formulas produced grade 2 mushrooms. The oyster mushrooms produced in this grade were uniform in size $(\leq 20 \%)$ and maturity $(\leq 10 \%)$, fresh $(\leq 10 \%)$, and clean with reasonably free from deformation $(\leq 10 \%)$ and damage $(\leq 5 \%)$. Based on the same standard for the size classification of cap diameter, seven substrate formulas $(6.70-7.87 \mathrm{~cm})$ were labelled as size code $2(\mathrm{M})$, whereas $100 \mathrm{SB}$ $(8.37 \mathrm{~cm})$ and 50SD:50SF $(8.07 \mathrm{~cm})$ were labelled as size code $3(\mathrm{~L})$.

According to FAMA (2012), the criteria of effective fruiting body, which is known as the edible mushroom part of mature grey oyster mushroom, can be identified when the cap is a grey, expanded, and has a thin flattened surface, while the gills are white with wider gaps. The mean number of the effective fruiting bodies per bunch was recorded, and the results showed no significant differences between the substrate formulas (Table 1). The results showed that the maximum effective fruiting bodies number of $P$. sajor-caju ranged between
1.70 and 2.16 bodies per bunch for all substrate formulas. Based on a previous study in the same field of interest by Onuoha (2007), SD had the least number of body fruiting production than other substrates, which agreed with the results of this study.

The fruiting bodies weight ( $\mathrm{g} / \mathrm{bunch}$ ) of P. sajor-caju depends on the cap diameter, stipe length, and total number of effective fruiting bodies per bunch. The fruiting bodies weight is also affiliated with the yield and $\mathrm{BE}$ of mushrooms. The weight grown on totally non-identical substrate formulas was significantly different from each other (Table $1)$. The highest fruiting bodies weight of $P$. sajor-caju (29.36 g/bunch) was obtained from 50SD:50SF substrate. Meanwhile, the lowest fruiting bodies weight was recorded for 75SD:25SB substrate (19.17 g/bunch). The fruiting bodies yield from this study consisting of SD, SB, and SF was lower compared to other studies, as obtained from previous studies. Fasehah and Shah (2017) recorded a mean yield of $42.83 \mathrm{~g} / \mathrm{bunch}$ using SD as a substrate, whereas Haastrup and Aina (2019) obtained a mean yield of $45.15 \mathrm{~g} / \mathrm{bunch}$ of mushrooms. However, based on this study alone, SF has a higher potential as a substrate than SB in terms of fruiting bodies yield.

\section{Effects of Various Substrate Formulas on Grey Oyster Mushroom Yield and BE}

The main purpose of mushroom cultivators is its yield. For this study, the fruiting bodies of P. sajor-caju (in three successive flushes) were gathered from substrate 
bags $(500 \mathrm{~g})$. Pleurotus sajor-caju grown harvested. There was no specific pattern in on various substrate formulas showed the mushroom yield (Table 2) from first, significant differences in the mushrooms second, and third flushes.

Table 2

Effect of various substrate formulas on fruiting bodies yield and BE of Pleurotus sajor-caju

\begin{tabular}{cccccc}
\hline $\begin{array}{c}\text { Substrate } \\
\text { formula }\end{array}$ & $\begin{array}{c}1^{\text {st }} \text { flush } \\
(\mathrm{g} / \mathrm{bag})\end{array}$ & $\begin{array}{c}2^{\text {nd }} \text { flush } \\
(\mathrm{g} / \mathrm{bag})\end{array}$ & $\begin{array}{c}3^{\text {rd }} \text { flush } \\
(\mathrm{g} / \mathrm{bag})\end{array}$ & $\begin{array}{c}\text { Total yield } \\
(\mathrm{g} / \mathrm{bag})\end{array}$ & $\begin{array}{c}\text { BE } \\
(\%)\end{array}$ \\
\hline 100SD & $25.82 \pm$ & $21.69 \pm$ & $30.48 \pm$ & $77.99 \pm$ & $15.60 \pm$ \\
& $11.01^{\mathrm{a}}$ & $4.40^{\mathrm{ab}}$ & $4.08^{\mathrm{a}}$ & $11.23^{\mathrm{a}}$ & $2.24^{\mathrm{ab}}$ \\
75SD 25SB & $21.27 \pm$ & $18.01 \pm$ & $18.21 \pm$ & $57.49 \pm$ & $11.50 \pm$ \\
& $4.98^{\mathrm{a}}$ & $2.39^{\mathrm{a}}$ & $4.16^{\mathrm{a}}$ & $8.20^{\mathrm{ab}}$ & $1.64^{\mathrm{b}}$ \\
50SD 50SB & $21.08 \pm$ & $21.84 \pm$ & $18.14 \pm$ & $61.06 \pm$ & $12.21 \pm$ \\
& $5.40^{\mathrm{a}}$ & $4.60^{\mathrm{ab}}$ & $3.17^{\mathrm{a}}$ & $12.11^{\mathrm{a}}$ & $2.42^{\mathrm{b}}$ \\
25SD 75SB & $20.07 \pm$ & $16.77 \pm$ & $22.26 \pm$ & $59.10 \pm$ & $11.82 \pm$ \\
& $3.00^{\mathrm{a}}$ & $2.13^{\mathrm{a}}$ & $3.22^{\mathrm{a}}$ & $1.75^{\mathrm{ab}}$ & $0.35^{\mathrm{b}}$ \\
100SB & $24.19 \pm$ & $19.90 \pm$ & $20.91 \pm$ & $65.00 \pm$ & $13.00 \pm$ \\
& $1.46^{\mathrm{a}}$ & $6.59^{\mathrm{ab}}$ & $6.61^{\mathrm{a}}$ & $5.27^{\mathrm{a}}$ & $1.05^{\mathrm{ab}}$ \\
$75 \mathrm{SD} 25 \mathrm{SF}$ & $21.75 \pm$ & $22.26 \pm$ & $25.55 \pm$ & $69.56 \pm$ & $13.91 \pm$ \\
& $7.38^{\mathrm{a}}$ & $4.90^{\mathrm{ab}}$ & $9.38^{\mathrm{a}}$ & $10.12^{\mathrm{a}}$ & $2.02^{\mathrm{ab}}$ \\
50SD 50SF & $38.91 \pm$ & $32.32 \pm$ & $16.86 \pm$ & $88.09 \pm$ & $17.62 \pm$ \\
& $10.38^{\mathrm{ab}}$ & $4.24^{\mathrm{b}}$ & $1.98^{\mathrm{a}}$ & $15.57^{\mathrm{ac}}$ & $3.11^{\mathrm{a}}$ \\
25SD 75SF & $18.21 \pm$ & $15.89 \pm$ & $27.05 \pm$ & $61.15 \pm$ & $12.23 \pm$ \\
& $2.13^{\mathrm{ac}}$ & $2.73^{\mathrm{a}}$ & $10.70^{\mathrm{a}}$ & $9.68^{\mathrm{a}}$ & $1.93^{\mathrm{b}}$ \\
100SF & $21.06 \pm$ & $23.00 \pm$ & $23.60 \pm$ & $67.66 \pm$ & $13.53 \pm$ \\
& $5.52^{\mathrm{a}}$ & $7.08^{\mathrm{ab}}$ & $7.40^{\mathrm{a}}$ & $4.08^{\mathrm{a}}$ & $0.82^{\mathrm{ab}}$ \\
\hline
\end{tabular}

Note. Significant at 0.05 level in ANOVA; mean values with the same lower-case letters are not significantly different according to Tukey HSD's mean separation test. SD, sawdust; SB, Sago bark; SF, Sago frond

Based on Table 2, the total yield of $P$. sajor-caju ranged from 57.49 to $88.09 \mathrm{~g} /$ bag. The significantly highest mushroom yield was acquired for 50SD:50SF (88.09 $\mathrm{g} / \mathrm{bag})$. A ratio of $75 \mathrm{SD}: 25 \mathrm{SB}$ produced the least mushroom harvest (57.49 $\mathrm{g} / \mathrm{bag})$, and there was no significant difference from the substrate formula 25SD:75SB (59.10 g/bag).
$B E$ is an excellent parameter to determine the potential of substrate transformation within the fruiting body. Most of the time, substrates with a higher yield produced a higher BE. The higher the BE, the higher the substrate's applicability for mushroom cultivation as the substrate's BE indicates their applicability to support 
the expansion of mushroom strain (Megersa et al., 2013). From Table 2, the substrate formula of 75SD:25SB showed the lowest BE (11.50\%), whereas 50SD:50SF obtained the highest BE (17.62\%). However, there were no significant differences of $\mathrm{BE}$ between 75SD:25SB and 25SD:75SB (11.82\%), 50SD:50SB (12.21\%), and 25SD:75SF (12.23\%). In general, the BE of $P$. sajor-caju in the present research is much lower than the study done by Ahmed et al. (2013). These results also differed from the study by Pathmashini et al. (2008), in which the best biological yield for oyster mushroom was achieved for the substrate containing SD. The variations in the yield and BE of P. sajor-caju full-grown on completely different substrate formulas are due to variations of the substrate formulas' physical and chemical composition. Based on the fruiting bodies yield and BE from this study, it is shown that SD incorporated with SF enhanced the yield compared to SD alone and incorporated with SB as a substrate.

\section{CONCLUSION}

Mushroom production largely depends on the quality of spawn, which is based on substrates. Based on the results, the substrate mixtures of SD with SF have a better fruiting bodies yield and higher BE on Pleurotus sajor-caju grown compared to $\mathrm{SD}$ with SB and SD alone. The evaluation of $\mathrm{SB}$ and SF at different ratios gives positive results, where the ratio with a high amount of SB and SF can produce fruiting body effectively. The present study indicates that SB and SF waste can be used and further developed for local growers' mushroom cultivation. SB and SF can be utilised as one of the substitutional substrates to replace SD in the cultivation of oyster mushroom.

\section{ACKNOWLEDGEMENTS}

The authors would like to thank the Tun Openg Chair Grants for the support through the grant (F07/TOC/1739/2018) and the Faculty of Resource Science and Technology, Universiti Malaysia Sarawak for allowing this experiment to be conducted in their facilities.

\section{REFERENCES}

Ahmed, M., Abdullah, N., Ahmed, K. U., \& Bhuyan, M. H. M. (2013). Yield and nutritional composition of oyster mushroom strains newly introduced in Bangladesh. Pesquisa Agropecuária Brasileira, 48(2), 197-202. https://doi.org/10.1590/S0100204X2013000200010

Auldry, C. P., Ahmed, O. H., Nik Muhamad, A. M., Nasir, H. M., \& Jiwan, M. (2009). Production of potassium and calcium hydroxide, compost and humic acid from sago (Metroxylon sagu) waste. American Journal of Environmental Sciences, 5(5), 664-668. https://doi.org/10.3844/ ajessp.2009.664.668

Awg-Adeni, D. S., Abd-Aziz, S., Bujang, K., \& Hassan, M. A. (2009). Bioconversion of sago residue into value added products. African Journal of Biotechnology, 9(14), 2016-2021. https://doi.org/10.5897/AJB10.009

Bugarski, D., Gvozdenovic, D., Takac, A., \& Cervenski, J. (1994). Yield and yield components of different strains of oyster mushroom. Savremena Poljoprivreda (Yugoslavia), 42(1), 314-318. 
Cardoso, J. C. P., Demenjour, P. L. M. M., \& Paz, M. F. (2013). Cultivo do cogumelo comestível Pleurotus ostreatus em bagaço de bocaiuva e de cana-de-açúcar pelatécnica jun-cao [Cultivation of the edible mushroom Pleurotus ostreatus in Bocaiúva and sugarcane bagasse by the Jun-Cao technique]. Evidência, 13(1), 31-40.

Das, N., \& Mukherjee, M. (2007). Cultivation of Pleurotus ostreatus on weed plants. Bioresource Technology, 98(14), 2723-2726. https://doi. org/10.5897/AJAR2016.11009

Emiru, B., Zenebech, K., \& Kebede, F. (2016). Effect of substrates on the yield, yield attribute and dietary values of oyster mushroom (Pleurotus ostreatus) in the pastoral regions of Northern Ethiopia. African Journal of Food, Agriculture, Nutrition and Development, 16(4), 11198-11218.

Fasehah, S. N., \& Shah, A. (2017). Effect of using various substrates on cultivation of Pleurotus sajor-caju. Journal of Engineering Science and Technology, 12(4), 1104-1110.

Federal Agricultural Marketing Authority. (2012). Kualiti cendawan tiram kelabu berpandukan Malaysian standard (MS 2515:2012) [Quality of grey oyster mushroom based on Malaysian standard (MS 2515:2012)]. FAMA. http:// www.fama.gov.my/documents/20143/0/ cendawan+red.pdf/63676187-392a-48ce-44056d4090cb5568

Haastrup, N. O., \& Aina, O. A. O. (2019). Comparative study on the growth and yield of Pleurotus sajor-caju mushroom cultivated on Pennisetum Purpureum (elephant grass) and saw dust of Triplochiton Scleroxylon as an environmental control measure. International Journal of Research and Innovation in Applied Science, 4(6), 53-55.

Hisahima, S. (1995, December 11-14). Sago palm, a promising renewable carbohydrate resource: A material for environmental conservation and sustainable development [Paper presentation].
Proceedings of the UNESCO - University of Tsukuba International Seminar on Traditional Technology for Environmental Conservation and Sustainable Development in the Asian-Pacific Region, Tsukuba, Japan. https://www.eubios. info/TTEC/TTECHS.htm

Kuroda, K. I., Ozawa, T., \& Ueno, T. (2001). Characterization of sago palm (Metroxylon sagu) lignin by analytical pyrolysis. Journal of Agricultural and Food Chemistry, 49(4), 18401847. https://doi.org/10.1021/jf001126i

Megersa, S., Feleke, S., Tekleyohannes, A. T., \& Gezahegn, A. (2013). Suitability of various lignocellulosic substrates for cultivation of Pleurotus sajor-caju (oyster mushroom). Ethiopian Journal of Agricultural Sciences, 23(1-2), 29-40.

Naraian, R., Sahu, R. K., Kumar, S., Garg, S. K., Singh, C. S., \& Kanaujia, R. S. (2009). Influence of different nitrogen rich supplements during cultivation of Pleurotus florida on corn cob substrate. The Environmentalist, 29(1), 1. https:// doi.org/10.1007/s10669-008-9174-4

Ngaini, Z., Noh, F., \& Wahi, R. (2014). Esterified sago waste for engine oil removal in aqueous environment. Environmental Technology, 35(22), 2761-2766. https://doi.org/10.1080/09593330.2 014.920051

Onuoha, C. I. (2007). Cultivation of the mushroom (Pleurotus tuber regium) using some local substrates. Life Science Journal, 4(4), 58-61.

Osunde, M. O., Olayinka, A., Fashina, C. D., \& Torimiro, N. (2019). Effect of carbon-nitrogen ratios of lignocellulosic substrates on the yield of mushroom (Pleurotus pulmonarius). Open Access Library Journal, 6, e5777. https://doi. org/10.4236/oalib.1105777

Pathmashini, L., Arulnandhy, V., \& Wijeratnam, R. S. (2008). Cultivation of oyster mushroom (Pleurotus ostreatus) on sawdust. Ceylon Journal of Science (Biological Science), 37(2), 177-182. http://doi.org/10.4038/cjsbs.v37i2.505 
Rajyalakshmi, P. (2004). Caryota palm sago - A potential yet underutilized natural resource for modern starch industry. Natural Product Radiance, 3(3), 144-149.

Royse, D. (2002). Influence of spawn rate and commercial delayed release of nutrient levels on Pleurotus cornucopiae (oyster mushroom) yield, size and time to production. Applied Microbiology and Biotechnology, 58(4), 527531. https://doi.org/10.1007/s00253-001-0915-2

Shah, Z. A., Ashraf, M., \& Ishtiaq, M. (2004). Comparative study on cultivation and yield performance of oyster mushroom (Pleurotus ostreatus) on different substrates (wheat straw, leaves, saw dust). Pakistan Journal of Nutrition, 3(3), 158-160. https://doi.org/10.3923/ pjn.2004.158.160
Tsujiyama, S. I., \& Ueno, H. (2013). Performance of wood-rotting fungi-based enzymes on enzymic saccharification of rice straw. Journal of the Science of Food and Agriculture, 93(11), 28412848. https://doi.org/10.1002/jsfa.6118

Zhang, R., Li, X., \& Fadel, J. G. (2002). Oyster mushroom cultivation with rice and wheat straw. Bioresource Technology, 82(3), 277-284. https:// doi.org/10.1016/s0960-8524(01)00188-2 